\title{
International Emergence of Forensic Accounting Education and Practice
}

\author{
Zabihollah Rezaee1, Danny Lo², Michael Ha ${ }^{3}$ \\ ${ }^{1}$ Fogelman College of Business \& Economics, The University of Memphis, Memphis, USA \\ ${ }^{2}$ International Business School Suzhou, Xi'an Jiaotong-Liverpool University, Suzhou, China \\ ${ }^{3}$ Department of Mathematical Sciences, Xi'an Jiaotong-Liverpool University, Suzhou, China \\ Email: zrezaee@memphis.edu, danny.lo@xjtlu.edu.cn, Michael.Ha@xjtlu.edu.cn
}

Received September 2014

\begin{abstract}
Forensic accounting practice has emerged in the areas of litigation support consulting, expert witnessing, and fraud investigation. Although forensic accounting practice is viewed as one of the most rewarding and secure career choices, there is a gap between forensic accounting practice and education. Thus, this study gathers opinions of international students regarding the importance demand, relevance, benefits, coverage, and delivery of forensic accounting education to international accounting students. Results indicate that: 1) the demand for and interest in forensic accounting education and practice will continue to increase worldwide; 2) forensic accounting can be integrated to the business curriculum by either offering a stand-alone forensic accounting course or through infusion into several accounting and business courses; and 3) many of the suggested forensic accounting topics should be integrated into business and accounting curricula in universities worldwide. The findings can be of great benefit to business colleges and accounting schools worldwide in redesigning their curricula by providing coverage of the emerging area of forensic accounting.
\end{abstract}

\section{Keywords}

Forensic Accounting Practice and Education, Business and Accounting Curricula, Financial Statement Fraud

\section{Introduction}

Forensic accounting practice has emerged in the areas of litigation support consulting, expert witnessing, and fraud investigation [1]. Although forensic accounting is viewed as one of the most rewarding and secure career choices, there is still a gap between forensic accounting practice and education. The extant literature in the United States (Rezaee et al., 2007) provides evidence of the importance of forensic accounting education and practice and its integration into the business curriculum. However, the evidence of forensic accounting practice and education in other countries particularly China is rare. Thus, the primary purposes of this paper are to: 1) describe areas of forensic accounting practices from a global perspective; 2) examine the demand for and interest in forensic accounting practices and education worldwide: and 3) present the most relevant forensic accounting topics to be 
integrated into the global business curriculum.

\section{Literature Review}

Rezaee, Crumbley and Elmore [2] conducted a survey of both academics and practitioners in the United States and find that both groups of respondents considered forensic accounting education as being relevant and useful to accounting students, and suggested forensic accounting topics should be integrated into the accounting curriculum. Rezaee and Riley [3] report that since the passage of the Sarbanes-Oxley Act of July 2002 (SOX), which was primarily intended to combat FSF and scandals, the Department of Justice has obtained nearly 1300 fraud convictions. Forensic accounting first appeared in the United States in the late 1870s and early 1880s due to stock fraud cases and scandals involving the securities market and the credit industry. The rapid growth of forensic accounting in China did not take place until the end of the 20th century. The term "forensic accounting" is still unfamiliar to many in China, but many know what "judicial accounting” means [4].

A survey of Chinese professionals conducted in 2005-2006 finds that the promotional strength of forensic accounting in China is insufficient with low social awareness [5] [6]. Thus, there are still many loopholes in the accounting laws. Some laws and regulations such as the Evidence Act, Investment Act and Property Law need to be regulated tightly [7]. In the supply of forensic accounting in China, there is no specific organization which could provide the forensic accounting service. The Shanghai Forensic Accounting Identification Committee has been concerned about public interests of addressing the accounting materials in the cases including economic crime, economic dissension, and civil disputes [8]. However, the organization basically still provides the same services as prior to the surge in forensic accounting.

\section{Method and Procedures}

A two-page, four-section questionnaire was prepared, pretested, revised, and then sent to the participants. The three main sections of the survey asked respondents for their perceptions of the future demand for and interest in all three areas of forensic accounting practices, ways that forensic accounting education can be integrated into the accounting curriculum and educational content of forensic accounting education. The last section sought comments on forensic accounting education and practice and financial reporting fraud.

A survey was conducted at 2 different universities located in Suzhou, China. The first group consisted of 167 senior Financial Mathematics students at Xi'an Jiaotong-Liverpool University and the second group consisted of 123 graduate school students at SKEMA Business School on its China campus located in Suzhou. The surveywas conducted primarily because of students' education and work experience in business, financial reporting knowledge, and familiarity with areas of forensic accounting practices. Senior Chinese and international students from these universities were selected because: 1) Xi'an Jiaotong-Liverpool University is a Sino-British university offering 24 degree programs in the fields of Mathematics, Science, Engineering, Business, Management and Culture; 2) the language of instruction is English; 3) two of the authors are the instructors at Xi'an JiaotongLiverpool University; 4) one of the authors was the instructor of a Year 4 Financial Risk Management offered in the Fall semester of 2013 when the survey was conducted; 5) one of the authors was the instructor of Corporate Finance at SKEMA Business School. The questionnaire was administered by the author in 2 classes with a combination of 186 Chinese students and 114 international students.

\section{Results and Discussions}

The majority of both groups of respondents (Chinese and international students) reported that they expect future demand for and interest in fraud examination, expert witnessing and litigation support services with the highest interest in litigation support. Results indicate that majority of both groups of respondents believe that forensic accounting courses should be offered at graduate, undergraduate and/or both graduate and undergraduate levels. Results also show that both groups of respondents agreed that Corporate governance plays an important role in preventing and detecting fraud, forensic accounting education and antifraud policies and procedures should be integrated into the accounting curriculum.

We asked both groups of respondents to indicate the importance of 21 suggested forensic accounting topics. Results reveal that Chinese students rank the importance of these 21 topics for integration into the accounting curriculum much higher that international students and differences in many responses (19 out of 21) are statisti- 
cally significant. Results show that both Chinese and international students ranked the topics "financial statement fraud", "legal elements of fraud" and "antifraud education and practice" at the top of their list. The main disparity between the two groups involved the topic of "types of fraud," and "cyber and computer fraud" which was ranked as one and six by international students respectively and as low as 14th and 20th by Chinese students respectively. Chinese students tend to rank fraud-type and cyber and computer fraud lower than international students. Chinese students show more interest than international students in the coverage of fraud examination including topics such as financial statement fraud, legal elements of fraud, environment and business red flags, elements of fraud, anti-fraud criteria and professional standards pertaining to forensic accounting. While international students consider fraud examination important, they placed more importance on topics pertaining to types of fraud, antifraud education and practice corporate governance and principles of ethics and corporate code of conduct.

\section{Conclusion}

Results show that the demand for and interest in forensic accounting practice is expected to continue to increase. Business schools and accounting programs throughout the world should respond to such demand by offering forensic accounting courses at either undergraduate and/or graduate levels. Furthermore, the majority of 21 suggested forensic accounting topics are considered as important by both groups of Chinese and international students for integration into the accounting curriculum. Results provide support for forensic accounting practices and education worldwide. The suggested forensic accounting topics can help business schools and accounting programs to customize their forensic accounting courses to meet expectations of their stakeholders.

\section{References}

[1] Rezaee, Z. (1992) Forensic Accounting: Challenges and Opportunities. The Ohio CPA Journal, 33-37.

[2] Rezaee, Z., Crumbley, L. and Elmore, R. (2004) Forensic Accounting Education: A Survey of Academics and Practitioners. Advances in Accounting Education Teaching and Curriculum Innovations, 6, 193-232. http://dx.doi.org/10.1016/S1085-4622(04)06010-9

[3] Rezaee, Z. and Riley, R. (2009) Financial Statement Fraud: Prevention and Detection. 2nd Edition, John Wiley \& Sons, Inc., Hoboken.

[4] Guo, Z., Wang, D., Ji, L. and Dang, X. (2005) A Comparison between Forensic Accounting and Judicial Accounting. Journal of Beijing Jiaotong University (Social Sciences Edition), 4.

[5] Zhang, D. and Zhang, K. (2010) Forensic Accounting: Legal Consideration and System Construction. Caikuai Yuekan (Monthly Journal of Accounting), 9, 6-8.

[6] Zhang, L. and Bo, H. (2010) Related Discussion about the Forensic Accounting Litigation Support Service. Caikuai Yuekan (Monthly Journal of Accounting), 4, 17-18.

[7] Sui, H. (2013) The Development Way of Forensic Accounting in China. Accounting and Finance Research, 2, 119122. http://dx.doi.org/10.5430/afr.v2n3p119

[8] Hao, X. (2010) Analysis of the Necessity to Develop Forensic Accounting in China. International Journal of Business and Management, 5, 185-187. http://dx.doi.org/10.5539/ijbm.v5n5p185 